\title{
Obtaining a protein concentrate based on cashew nut (Anacardium occidentale L.) and determination of food quality characteristics
}

\author{
Y.A. Marrugo-Ligardo ${ }^{1 *}$, L. Monroy-Rodriguez ${ }^{2}$, C.A. Severiche-Sierra ${ }^{3}$, J. Jaimes-Morales ${ }^{4}$, J.J. \\ Lafont-Mendoza ${ }^{5}$ \\ ${ }^{1-4}$ Universidad de Cartagena, MAAS Research Group on Environment, Food and Health. Cartagena de indias, \\ Bolívar, Colombia. \\ ${ }^{5}$ Universidad de Córdoba, Research Group Organic Physicochemistry. Monteria, Cordoba, Colombia.
}

*correspondence author: ymarrugol@unicartagena.edu.co

\begin{abstract}
The bromatological characteristics of the concentrate obtained from the cashew nut (Anacardium occidentale $L$.) with other known concentrates were compared, tests were performed and application in different food products were evaluated their sensory characteristics. The results of obtaining the cashew nut concentrate reveal the full potential source of proteins for human nutrition, which can be used directly in processed products. The functional properties of the concentrate do not distance from the properties of other known ones, which suggests the possibility of being used in multiple food products.
\end{abstract}

Keyword- Protein content, Food technology, Nutritional quality.

\section{INTRODUCTION}

The cashew tree (Anacardium occidentale L.), is a wild tree that belongs to the Anacardiaceae family, native to the tropical areas of America and northwestern Brazil, which has excellent medicinal and nutritional properties [1,2]; It has low branching and variable average height of 5 to 14 meters, depending on the genotype and climatic condition, its fruit can be red and yellow, it is astringent and nutritional, it contains $47 \%$ fat, $21 \%$ protein and $22 \%$ carbohydrates, vitamins and amino acids, the fruit is attached to a pseudo fruit or nut of gray color and kidney shape with a chemical composition of $46.3 \%$ of oil with respect to its total weight $[3,4]$.

Cashew (Anacardium occidentale L.) is a fruit that is well established throughout the tropical world, found from the United States to southern Africa. Among the countries with the highest concentration of crops besides Brazil, there is India, Kenya, Mozambique and Tanzania [5]. In Colombia, the main objective of the cashew crop is the nut, with an approximate production of 5000 tons [6].

The use or application of a protein isolate as an ingredient of a food depends of its quality. Therefore it is necessary that once a protein isolate has been produced, it must be evaluated in two ways: (1) from the nutritional point of view and (2) from the functional point of view [7,8]. Proteins that are utilised in food processing are of various origins, and can be roughly grouped into animal proteins (e.g. gelatine), vegetable proteins (e.g. soya protein, peanut protein and wheat protein), and animal-derivatives protein (e.g. milk proteins) [9].

In spite of the great applicability of all parts of the cashew plant, at present no studies have been reported on the food quality characteristics associated with protein concentrates of cashew nut for purposes; From this point of view, this work aims to provide new data that serve as a basis for future research. The objective of this work is to obtain a protein concentrate based on cashew nut (Anacardium occidentale L.) and to determine its bromatological and functional properties. 


\section{Materials ANd Methods}

\section{Raw material and Preparation of samples}

Cashew nuts (Anacardium occidentale L.) were used in an optimal heavy maturing and without any fissures; bumps or deterioration. The seeds come from the municipality of María La Baja and Simití, South of Bolívar (Colombian Caribbean), were chosen from the red varieties, which have the largest nut. To obtain the flour samples, it was proposed to carry out the following stages shown in Figure 1.

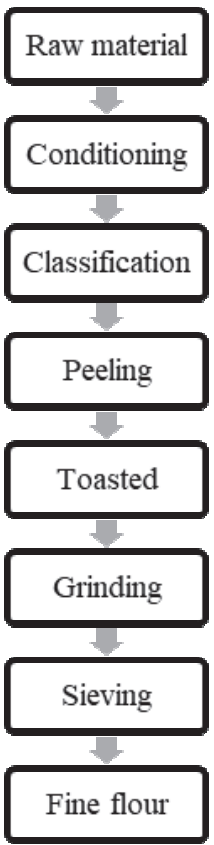

Figure I. Process for obtaining cashew nut flour (Anacardium Occidentale L.)

\section{Bromatological Analysis}

The bromatological analyzes were carried out following the methodology used by the Association of Official Analytical Chemists AOAC (1997) [10], making the following determinations: humidity, taking the weight difference of the sample and drying to constant weight $\left(\mathrm{N}^{\circ}\right.$ 938.08); raw fat, using the Soxhlet extraction technique (No. 920.39); The dietary fiber was determined with method No. 985.29; raw protein, by the Kjeldahl method where a factor of 6.25 was used to determine the total percentage (No. 976.05), and ashes (No. 942.05).

\section{Analysis of Concentrated Functional Properties}

The functional properties tests performed on the protein concentrate obtained from the cashew nut were: water retention capacity, lipid adsorption index, apparent density, swelling capacity, the methodology established for Marrugo et al. (2012) [11] for the previous parameters.

On the other hand, with respect to the foaming properties, it is well known that aqueous solutions have the ability to make foams, in the presence of a large gaseous mass, by shaking or stirring. These can be evaluated by determining the following characteristics: foam expansion capacity (C.E.E), foam density and foam stability (E.E), for all these parameters the methodology of Jaimes et al. (2014) [12].

\section{Protein Extraction}

The methodology used for the extraction of the proteins was the humid alkaline for which a certain quantity of raw material was taken and water was added in an established ratio and the $\mathrm{pH}$ was adjusted to the desired one; temperature and time were applied with stirring, then decanting, supernatant, precipitation, filtering, drying to finally obtain the protein concentrate [13]. 


\section{III.RESULTS AND DISCUSSION}

The estimated yield of the nut for the process was $21.5 \%$ for each kilogram of seeds, $215 \mathrm{~g}$ of ready-to-use almonds were obtained. Once the raw material was reduced to flour, it was bromatologically characterized. The results of Table 1 were obtained, which fulfill the expectations regarding their nutritional composition.

Table I. Characterization of cashew nut flour (Anacardium
\begin{tabular}{|c|c|}
\hline Component & Percentage (\%) \\
\hline Proteín & 23.3 \\
\hline Grease & 45 \\
\hline Fiber & 1.2 \\
\hline Wet & 7.3 \\
\hline Ash & 2.5 \\
\hline
\end{tabular}

Comparing its protein content with those obtained by Marrugo et al. (1016) [14] that of other very common seeds we can note the competitiveness of the Marañón almond, only being below Peas (24.9\%) and Jewish $(27.1 \%)$.

With regard to obtaining the protein concentrate, we start with a raw material-solvent ratio of $1.15(\mathrm{~g} / \mathrm{mL})$, an alkaline $\mathrm{pH}$ of 9 , time and agitation 30 minutes with a temperature of $50{ }^{\circ} \mathrm{C}$, later the soluble protein precipitated at $\mathrm{pH} 4.5$ [15]. The different tests performed are presented in Table 2, as well as the parameters followed in each one with their respective performance.

Table II. Tests carried out and parameters for obtaining the concentrate

\begin{tabular}{|c|c|c|c|c|c|c|c|c|c|}
\hline Test & $\begin{array}{c}\text { Sample } \\
(\mathrm{g})\end{array}$ & $\begin{array}{c}\text { Relationship } \\
\mathrm{g} / \mathrm{mL}\end{array}$ & $\begin{array}{c}\mathrm{pH} \\
\text { alkaline }\end{array}$ & $\begin{array}{c}\text { Time } \\
(\mathrm{min})\end{array}$ & $\begin{array}{c}\text { Temperature } \\
\mathrm{C}^{\circ}\end{array}$ & $\begin{array}{c}\mathrm{pH} \\
\text { precipitation } \\
(\mathrm{u} . \mathrm{pH})\end{array}$ & $\begin{array}{c}\text { Product } \\
\text { obtained } \\
(\mathrm{g})\end{array}$ & $\begin{array}{c}(\%) \\
\text { Performance }\end{array}$ & $\begin{array}{c}(\%) \\
\text { Proteins }\end{array}$ \\
\hline$\# 1$ & 20 & $1: 15$ & 9.0 & 30 & 50 & 4.50 & 6.5 & 32.5 & 47.3 \\
\hline$\# 2$ & 20 & $1: 15$ & 10.0 & 50 & 50 & 4.56 & 8.2 & 41.0 & 47.7 \\
\hline$\# 3$ & 20 & $1: 15$ & 8.0 & 40 & 35 & 4.48 & 8.7 & 43.5 & 54.6 \\
\hline$\# 4$ & 20 & $1: 10$ & 8.0 & 35 & 35 & 4.51 & 7.5 & 37.5 & 36.6 \\
\hline$\# 5$ & 20 & $1: 10$ & 11.0 & 30 & 45 & 4.48 & 7.1 & 35.5 & 36.7 \\
\hline$\# 6$ & 20 & $1: 12$ & 10.5 & 45 & 32 & 4.51 & 7.2 & 36.0 & 29.7 \\
\hline
\end{tabular}

It is observed that with the conditions of test number 3 , the best result was obtained, in the same way the superiority of the Marañón concentrate with respect to its extraction performance is notorious compared to that of other raw materials (Soybean, Bean, Peas, Lentils, Garbanzo) [16], which suggests that, if it is a source in which you can focus on works for the technological development of the same, and why not, seek marketing and use in different products of mass consumption.

\begin{tabular}{|c|c|}
\multicolumn{2}{|c|}{ Table III. Characterization of the concentrate } \\
\hline Proteins & $54.6 \%$ \\
\hline Humidity & $7.0 \%$ \\
\hline Grease & $25.0 \mathrm{v}$ \\
\hline Fiber & $1.0 \%$ \\
\hline Ashes & $0.3 \%$ \\
\hline Texture & Soft \\
\hline Color & White bone \\
\hline
\end{tabular}

The results of obtaining the cashew nut concentrate show all the potential source of proteins for human nutrition, being able to use it directly in processed products, in this sense the data that support this detail are gathered in Table 4.

Table IV. Functional properties compared with other concentrates

\begin{tabular}{|c|c|c|c|c|c|c|}
\hline Raw & Lipid absorption & Water & $\begin{array}{c}\text { Expansion } \\
\text { of the foam }\end{array}$ & $\begin{array}{c}\text { Expansion } \\
\text { of the foam }\end{array}$ & $\begin{array}{c}\text { Emulsifying } \\
\text { activity }\end{array}$ & $\begin{array}{c}\text { Stability of } \\
\text { the emulsion }\end{array}$ \\
\hline
\end{tabular}




\begin{tabular}{|c|c|c|c|c|c|c|}
\hline $\begin{array}{c}\text { Cashew } \\
\text { nut }\end{array}$ & 6 & 440 & 300 & 10.0 & 48.0 & 62 \\
\hline Soy & 306 & 346 & 251 & 12.0 & - & - \\
\hline $\begin{array}{c}\text { Broad } \\
\text { beans }\end{array}$ & 176 & 220 & 251 & 4.0 & - & - \\
\hline $\begin{array}{c}\text { Bean } \\
\text { Saragossa }\end{array}$ & 220 & 340 & 318 & 8.1 & - & - \\
\hline $\begin{array}{c}\text { Palm } \\
\text { kernel cake }\end{array}$ & 4.5 & 460 & - & - & 43.4 & $70 \%$ \\
\hline
\end{tabular}

\section{IV.CONCLUSIONS}

From the results obtained, the following conclusions can be presented: The yields of the extraction of the concentrate satisfy all the expectations, being superior even to conventional sources such as soybean, bean, chickpea, etc. Similarly, the yield of protein in the concentrate had a highly representative value compared to other sources of concentrates. Finally, the functional properties of the concentrate do not distance it from the properties of other known ones, which suggests the possibility of being used in multiple food products.

\section{References}

[1] S. Omosuli, S. Ibrahim., D. Oloye., R. Agbaje., B. Jude, Proximate and mineral composition of roasted and defatted cashew nut (Anacardium occidentale) flour, Pakistán Journal of Nutrition, 8, (2009), 1649-1651.

[2] M. Siddique, P. Maresca, G. Pataro and G. Ferrari, Influence of pulsed light treatment on the aggregation of whey protein isolate, Food Research International, 99, (2017), 419-425.

[3] J. Lafont, S. Páez and A. Portacio, Extracción y Caracterización Fisicoquímica del Aceite de la Semilla (Almendra) del Marañón (Anacardium occidentale L). Información tecnológica, 22, (2011), 51-58.

[4] S. Ogunwolu, F. Henshaw, H. Mock, A. Santros and S. Awonorin. Functional properties of protein concentrates and isolates produced from cashew (Anacardium occidentale L.) nut, Food Chemistry, 115, (2009), 852-858.

[5] L. Mestres, J.M. Souquet., H.Fulcrand., C. Bouchut., M. Reines and J.M. Brillouet. Monomeric phenols of cashew apple (Anacardium occidentale L), Food Chemistry, 112, (2009), 851-857.

[6] G. Arrázola, A. Alvis and M. Osorio. Clarificación combinada y evaluación sensorial de jugo de marañón (Anacardium occidentale L.). Revista MVZ Córdoba, 18, (2013), 3722-3730.

[7] K.P. Prabhakaran Nair, 2 - Cashew Nut (Anacardium occidentale L.), In The Agronomy and Economy of Important Tree Crops of the Developing World, Elsevier, London, 2010, Pages 21-66, ISBN 9780123846778.

[8] J.I. Boye, S. Aksay, S. Roufik, S. Ribéreau, M. Mondor, E. Farnworth and S.H. Rajamohamed, Comparison of the functional properties of pea, chickpea and lentil protein concentrates processed using ultrafiltration and isoelectric precipitation techniques, Food Research International, 43, (2010), 537-546.

[9] A.D. Berry and S.A. Sargent, 19 - Cashew apple and nut (Anacardium occidentale L.), In Woodhead Publishing Series in Food Science, Technology and Nutrition, edited by Elhadi M. Yahia,, Woodhead Publishing, 2011, Pages 414-422, 423e, Postharvest Biology and Technology of Tropical and Subtropical Fruits, ISBN 9781845697341.

[10] AOAC, 1997. Official Methods of the Association of Official Analytical Chemist, 16th ed. Washington, DC.

[11] Y. Marrugo, P. Montero and M. Duran, Functional properties of protein concentrates of Phaseolus lunatus and Vigna unguiculata, Vitae, 19, (2012), S403-S405.'

[12] J. Jaimes, D. Restrepo and D. Acevedo, Preparation and determination of the functional properties of the trupillo proteic concentrated (Prosopis juliflora), Biotechnology in the Agricultural and Agroindustrial Sector, 12, (2014), 144-152.

[13] J. Jaimes, A. Acosta, C. Severiche, Y. Marrugo and E. Bedoya, Evaluation of the Functional Properties of Prosopis juliflora Protein Concentrate Obtained by Different Methods, International Journal of Engineering and Technology, 9, (2017), 3841-3847.

[14] Y. Marrugo, P. Montero and M. Duran, Nutritional Evaluation of Concentrated Protein of Phaseolus lunatus and Vigna unguiculata, Technological Information, 27, (2016), 107-114.

[15] J. Jaimes, J. Torres and C. Severiche, Analysis of the quality of a blanched meat product made with Prosopis Juliflora flour, Ingenium. 9, (2015), $21-28$.

[16] Y. Marrugo, C. Vargas, C. Severiche, J. Jaimes and E. Bedoya, Evaluation of the Functional Properties of Bean Starch Zaragoza (Phaseolus lunatus) White Variety in a Food Type Sausage, International Journal of Engineering and Technology, 9, (2017), $3674-$ 3679. 